Portland State University

PDXScholar

Communication Faculty Publications and

Presentations

Communication

$10-1-2011$

\title{
'You're lying to Jesus!': Humor and Play in a Discussion About Homelessness
}

L. David Ritchie

Portland State University, cgrd@pdx.edu

Follow this and additional works at: https://pdxscholar.library.pdx.edu/comm_fac

Part of the Interpersonal and Small Group Communication Commons

Let us know how access to this document benefits you.

\section{Citation Details}

Ritchie, L. (2011). 'You're lying to Jesus!': Humor and play in a discussion about homelessness. Humor: International Journal Of Humor Research, 24 (4), 481-511.

This Article is brought to you for free and open access. It has been accepted for inclusion in Communication Faculty Publications and Presentations by an authorized administrator of PDXScholar. Please contact us if we can make this document more accessible: pdxscholar@pdx.edu. 


\title{
"You're lying to Jesus!" Humor and play in a discussion about homelessness
}

\author{
L. DAVID RITCHIE
}

Abstract

This study applies recent theories about humor to a sample of talk among a group of young adults about the issues and problems associated with homelessness. In this conversation, participants demonstrate a pattern of joking and language play that expresses a complex and ambivalent set of attitudes and feelings toward homelessness and toward the homeless as both outcasts and refugees from conventional society. Humor is used both to express complex responses to homelessness and as a tool for managing the tone and direction of the conversation. The results demonstrate how the identification of patterns of joking and wordplay can provide insights into how people accomplish task-oriented objectives as well as relational and interactive objectives in everyday talk.

Keywords: discourse; everyday talk; homelessness; humor.

\section{Introduction}

How does humor help us handle the problems posed by emotionally taxing issues such as those raised by our frequent encounters with homelessness? How does humor contribute to the process of attitude and belief formation in the crucible of everyday talk? How do people use humor to help negotiate conflicting social identities associated with significant life transitions?

This essay addresses these questions within a broader inquiry into the role of everyday conversation in the formulation, transmission, and expression of social reality, and a parallel inquiry into the role of figurative language, including humor, in the accomplishment of relational and task objectives in everyday 
talk. Informal talk about homelessness is a particularly useful focus for this inquiry, because, like many of the underlying issues in contemporary U.S. public life, the issues surrounding homelessness are complex and morally ambiguous. Homelessness touches most of us in one way or another on a daily basis, arouses an ambivalent mixture of emotions, and admits no ready or easy solution. Moreover, unlike other enduring issues such as abortion rights or gun control, views about issues associated with homelessness do not yet seem to have hardened or polarized: civil conversation on the topic is still easily accomplished in ordinary social settings. Finally, homelessness is associated both with social problems of unemployment, substance abuse, and mental illness on the one hand and on the other hand, at least within contemporary U.S. youth subculture, with an idealistic and romantic pursuit of anti-materialism in the guise of boheme ("beat" or "hippie") lifestyles.

\section{Humor in groups}

Modern theories of humor have generally emphasized aggression and superiority (e.g., Gruner 1997; Zillman and Cantor 1976), contrast, incongruity, or incongruity resolution (e.g. Raskin 1985; Raskin and Attardo 1994; Suls 1972), or tension-release (e.g. Lefcourt 2001). Citing Apter's (1982) characterization of humor as playful and paratelic (in contrast to goal-oriented or telic behavior, Martin (2007) insists that humor is "essentially a type of mental play involving a lighthearted, nonserious attitude toward ideas and events" (p. 1); Chiaro (1992) and Norrick (1993) make similar points. Martin concludes that aggression and superiority is often but not always involved in humor, and that some form of contrast or incongruity is always involved in the comprehension of humor, but he also distinguishes between the comprehension and the enjoyment of humor.

Theories of humor have often been based on and explained in terms of canned jokes, usually narratives building up to a punch line and often taken from "joke book" collections or joke pages of popular magazines (Attardo 1994; Martin 2007). At least in part, as Martin points out, this is an issue of methodology, since naturally-occurring humor does not readily lend itself to rigorous experimental methods. However, the theoretical understanding of humor as a communicative resource has been considerably enriched by discourse-analytic research on humor in conversations (e.g., Norrick 1993; Tannen 1984; recent examples include Everts 2003; Terrion and Ashforth 2002). Humor has been analyzed both in workplace groups (Holmes and Marra 
2002; Plester and Sayers 2007; Terrion and Ashford 2002), and in informal conversations among friends (Tannen 1984) and within family groups (Everts 2003; Norrick 1993).

It is evident that humor often plays a complex role in-group interactions (Attardo 1994; Martin 2007; Tannen 1984). Recent research (e.g., Everts 2003; Fine and De Soucey 2005; Holmes and Marra 2002; Plester and Sayers 2007) has shown that groups often develop unique styles and traditions of joking and teasing as part of group culture. Humor helps to define the group, delineating members from outsiders, establishing and maintaining commitment to the group, and expressing and reinforcing the boundaries of acceptable behavior within the group. Humor is used to soften implied criticisms and directives and to negotiate differences of power and authority; it can also be used by inferiors to challenge or subvert power and status hierarchies and to assert solidarity among members of subgroups. Other research (e.g. Terrion and Ashford 2002) highlights the social-facilitative and interpersonal bonding role of humor. When a complex or morally ambiguous topic is under discussion, humor may provide a means for introducing information and expressing responses that might otherwise seem mutually contradictory or otherwise reprehensible, and for introducing potentially offensive or controversial information and ideas while avoiding taking direct responsibility for them.

The work and family groups observed in recent research on humor often have clearly defined boundaries. Consistent with Social Identity Theory (Capozza and Brown 2000; Tajfel and Turner 1986) and the superiority / aggression theories of humor (e.g., Gruner 1997; Zillman and Cantor 1976) we would expect the humor in a clearly-defined group to be directed at out-groups or, when it is used within the group, to be used in a way that either reinforces the status hierarchy (when directed at less powerful members of the group) or subverts the status hierarchy (when directed at more powerful members of the group). However, within the family and friendship groups studied by Norrick (1993), much of the apparently aggressive humor was both welcomed and enjoyed by the apparent target of the "aggression," and seemed to build rather than undermine a spirit of conviviality; similar patterns are observed by Terrion and Ashford (2002) among the group of police executives they observed. On the other hand, in the groups studied by Drew (1987), much of the teasing had a barbed edge and was either rejected or repaired by the target, for example by correcting the teaser or reaffirming the serious state of affairs (Attardo 1994).

Gruner (1997) claims that all humor is aggressive, although he recognizes some aggressive humor as playful, similar to the mock aggression of "rough- 
and-tumble" play. However, as Martin (2007) points out, Gruner's claim is based on an obsolete theory of evolution and a definition of aggression that is so broad as to be unrefutable. Gruner also asserts that play always involves competition, and cannot be "fun" unless it involves the possibility of winning or losing, but Kohn (1986) provides extensive evidence that people often actively dislike competition and prefer non-competitive play. Even in roughand-tumble physical play, among both animals and humans the dominant animal usually "holds back" enough to permit the play-mate to "win" frequently (Martin 2007), thus mitigating the competition as well as the aggression. A rather different view of evolution is suggested by Dunbar (1996; 2003), and a contrasting view of language play is suggested by Carter (2004) and Cook (2000).

Drawing on growing evidence of a correlation between the size of the cerebral cortex and the complexity of social organization in several species of primates (as well as other mammals and birds), Dunbar proposes that the evolution of advanced cognitive abilities in general and language in particular has been in part driven by the pressures of living in large and complex social structures. Dunbar argues that language serves both as an extension of grooming behaviors observed among other primate species and as a means of exchanging information about the social structure of an extended group ("gossip"). Among other species of primates, grooming is used to build and maintain coalitions, and appears to function at least in part by means of the pleasure of being groomed. It is apparent from research on other species that play is also a source of pleasure; for example the opportunity to play has been found to serve as well as food as a reward in conditioning experiments (Fagen, 1995). Among humans, language play in particular, including nonsense as well as humor, is a source of pleasure among both adults and children (Cook 2000; Martin 2007).

Carter (2004) and Cook (2000) provide extensive examples demonstrating the extent to which humans, adults as well as children, derive enjoyment from playing with every aspect of language, from its sounds and rhythms through word meanings and narrative structures (for a discussion of playful and humorous use of metaphorical language see Glucksberg 2001 and Ritchie and Dyhouse 2008). Although Dunbar does not go into detail about the forms of language used as a substitute for and extension of physical grooming, it is well established that humor can relieve emotional stress and contribute to healing (Lefcourt 2001; Martin 2007), and a "grooming" function based on the mutual enjoyment of humor is certainly consistent with evidence that humor can contribute to group solidarity and bonding (Attardo 1994; Martin 2007). 


\subsection{Humor and the constitution of social reality amid conflicting social identities}

The research reported in the following was undertaken as part of a larger project designed to understand how socially intimate groups talk about politically, morally, and emotionally sensitive topics. An overarching objective of this project is to understand how groups constitute their understanding of external situations that affect them (their social reality) through their casual "everyday" conversations and simultaneously maintain themselves as coherent social units. A more immediate objective is to understand how figurative language contributes to a group's ability to negotiate a diversity of viewpoints within an overall commitment to group cohesion and solidarity. Thus, the objectives of the project combine research on the social processes of group cohesion with research on the distributed cognitive processes involved in establishing and formulating "positions" with respect to issues of mutual interest to group members.

Research on social identity has been criticized both for focusing on intergroup communication to the exclusion of communication within the group, and for emphasizing a single identity and ignoring the fact that multiple identities may operate simultaneously and sometimes in conflict with one another (Crisp and Hewstone 2000; Worchel et al. 2000). The group within which the conversation reported herein took place exemplifies yet another level of complexity. Consistent with Crisp and Hewstone, each member of this group has multiple social identities, and many of these come into play during the conversation. But most of the participants, half of whom are students, are also at a life stage at which social identities often undergo radical changes. Several of the participants in this conversation had, in the recent past, identified with a boheme, "hippie" life-style. To various degrees most of the participants were at the time of the conversation engaged in processes (pursuing college degrees, starting careers) that are at least to some extent contradictory with the antimaterialist, boheme values that had previously been professed by several of them. Because these values appear to be associated to some extent with the state of homelessness, the content of their discussion of homelessness was inevitably influenced by the apparent contradictions between their lingering boheme social identities and their emergent middle-class social identities. These within-person contradictions were emphasized by differences among the group members, which resulted in frequent bouts of joking and teasing.

During the initial analysis of the conversation reported herein, it became apparent that, in addition to the functions related to group identity, cohesion, and boundary-maintenance identified in previous research (Attardo 1994; 
Martin 2007), humor served a distinctly cognitive function, providing a vehicle through which group members were able to express and work out their complex personal responses to the emotionally charged and multi-faceted issues related to homelessness and poverty in the midst of comfort and plenty. For many of them, humor also provided a means to express the contradictions not only between the value commitments of different group members but also between the boheme values some members were relinquishing and the middleclass value commitments they were beginning to adopt. Finally, consistent with Dunbar's (1996) theory of the "grooming" function of language and Martin's (2007) observations about the social-bonding effects of shared pleasure, the humor also helped facilitate the social interaction by provided a basis for mutual enjoyment.

\section{The conversation}

The data analyzed herein were gathered by two students in an advanced seminar on figurative language and humor (Ellison and Boyer 2008), using a format based on the "peer group discussions" initially developed by Gamson (1992) and Sasson (1995). In contrast to more traditional focus groups, in "peer group discussions" participants are acquainted with each other outside of the research setting, fewer participants are used in each group, and the discussions are held in an informal social setting. Sasson argues that this approach encourages participants to interact more intensely and with less reserve and is more likely to give an accurate reflection of the subculture from which subjects are drawn.

\subsection{Participants}

For this study, six young adults, including two moderators, were invited to meet in the living room of one of the moderators and talk about issues related to homelessness. Three members of the group and one moderator are male, one participant and one moderator are female. The two moderators and one other participant are students at a large urban university in Portland, Oregon, a mid-sized western U.S. city. One of the males in the group, R, has himself been homeless on more than one occasion, for periods of time ranging from a few weeks to several months. $\mathrm{R}$ also appears to be the most politically sophisticated — and the most liberal — of the participants. The other partici- 
pants represent political and social views that range from moderately conservative to very liberal.

\subsection{Analysis}

To preserve anonymity, all participants are designated only by an initial. Details of transcription and coding are given in Appendix A. The transcribed data were first analyzed, using a combination of "bottom-up" and "top-down" analysis (Cameron 2007), for the pattern of metaphors and narratives (the results of the metaphor analysis are reported elsewhere). During this analysis, numerous instances of playful and humorous communicative behavior were noted. These include stories told with humorous intent, teasing and humorous insults exchanged between participants, and humorous meta-comments about the research process itself. Subsequent to the completion of the metaphor analysis, the instances of humor and play were identified and subjected to further analysis.

\subsection{Overview of the conversation}

A conversation held in the peer-group format can at best approximate a naturally-occurring conversation, and participants will inevitably be aware of the research setting. This awareness must be considered as part of the communicative context throughout the interpretation of the data (Gamson 1992; Sasson 1995). The participants in this conversation directly addressed the purposes of the research and joked about the research process itself several times during the conversation. Nonetheless, all participants seem to have been fully and sincerely engaged with the topic, and it is apparent from their joking and teasing that they participated in the conversation as an ordinary social interaction.

Several themes became apparent early in the analysis. Tensions between distance and empathy, boheme anti-materialistic and more conventional middleclass values, cynicism and pity, and person-blame vs. system-blame appeared early and re-appeared throughout. There were also frequent contrasts - between the city in which the conversation took place (Portland) and other cities in the U.S. and Europe (particularly New York and Amsterdam), between "real" homeless persons and "rich kids from the suburbs," between "the system" and "the street." Participants repeatedly mentioned that Portland attracts an unusual number of homeless people because the city is friendly to them - although on 
one of these occasions $\mathrm{R}$, the one member of the group who had actually been homeless, ironically noted that the homeless are shunted away from the center of the city into a permanent encampment called "Dignity Village."

Throughout the conversation one person would speak for several intonation units, usually a half-minute but sometimes longer, often interrupted by brief back-channel comments. Then several participants would make brief comments in response to the preceding monologue, and the pattern would be repeated. In most cases, at least one story was related or referenced during this prolonged turn. In some cases, a story was interrupted by another person's prolonged turn, then resumed and finished. Themes introduced in one story were frequently picked up, repeated, and sometimes transformed in later turns (see Cameron 2007).

\section{Humor}

Several examples of humor occur in connection with stories that make fun of homeless people or "the system." However, humorous stories also celebrate the humanity of homeless people, including stories in which homeless people get the better of "the system" in one way or another, and several instances of humor are at the expense of the person telling the story. Another large category of humor involves quips and jokes either about the research process or serving to deflate one or another of the participants, at least in part as a means of controlling the conversation.

\subsection{Making fun of the homeless}

The conversation opened with a pair of narratives about encountering homeless people, in which stock images of homeless panhandlers are invoked:

0139 S: I. . uh. . I'm the same way. Really don't think about it.

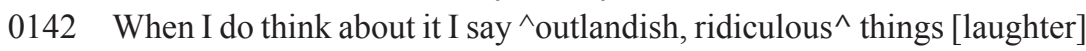

0145 Because its fun to be. . you know. . offensive and upsetting to people,

0149 but ... um. . It-its a lot of. . cliché things that come to mind.

0155 Like somebody standing on the side of. .

0157 the freeway, with $\mathrm{a}^{\wedge} \operatorname{sign}^{\wedge}$ and $\mathrm{a}^{\wedge} \operatorname{dog}^{\wedge} \ldots$

This "sign and a dog" image recurred repeatedly, often paired with a humorous comment. It was followed almost immediately by another narrative, which emphasized yet another homelessness stereotype: 
0222 P: Well did I tell you about. . the game that I made up

0225 When I moved downtown ... Called $\wedge^{\wedge}$ scare a bum away ${ }^{\wedge}$ ?

0227 S: [Laughs] $\mathrm{No}=\mathrm{O}$. . Oh yeah

[Laughter]

0229 P: I, I'd gotten. . I'd gotten frustrated with ^ walking downtown^.

0232 I couldn't leave a building ... and walk around a corner

0235 without getting asked for a cigarette [yup] or change..

0238 And so. . I. . thought about it and I was like. .

0240 What. . would be the one thing that would. . keep these people. .

0243 away from me

0245 And ... the concept is. . that. . no one wants to ask you for ${ }^{\wedge} \operatorname{shit}^{\wedge}$...

0249 If you look more fucked up than they are

S: Hmmmph [laughter]

0251 P: So basically. . you can usually spot a homeless person

0254 from about half a block away.

0256 And when you do you just, kinda, go into. . kinda ... of a retarded ...

0259 kinda walk and just stumble down the street

0301 or just get some really grimace face ... And just start talking to yourself. .

0305 And they don't ask you for shit.\} ... \{slowed, with emphasis\}

0308 S: No that's a fair thing. I might try that [laughter]

This basic avoidance narrative, with its implicit aggression and assertion of superiority with respect to homeless people is echoed several times in different versions, sometimes in a light and humorous tone, sometimes in a more serious tone.

Beginning a story about a panhandler who was at the same intersection for several months, S repeats a common stereotype: "And there were always the same. . bums. . bums? . . I don't know. . like. . I don- always the same fuckers out there. . with their fucking signs" Laughter] (S, 0927-0935). Switching from humor at the expense of the homeless to joking about the research process, P remarks, "Much better topic" (P, 0938), S replies, "Tran- Transcribe it, um. ." [Laughter] (S, 0939) and R exclaims "Ye=es."

Late in the conversation in a discussion about why homeless people all have dogs, S (4821) says "I also think they are a good pity button!" and R (4825) responds, "That's what babies are for. ." (general laughter). Here the humor is more complex, combining an implied denigration of homeless people with a subversive cynicism. 
Early in the conversation, participants draw a distinction between the genuinely down-and-out" homeless and "rich kids" who are merely "slumming." In response to one of R's stories about his own life "on the streets," B starts a question about the homeless subculture, then protests,

0407 Hey, I'm not the one from $\left\{{ }^{\wedge}\right.$ suburb $\left.^{\wedge}\right\}$. No [laughter] uh

0410 It's a bunch of rich kids. Like, it's this whole [cough]

0412 It's a dichotomy. You have real homeless people

0414 And then you have street kids or whatever [yeah]

0417 And it's ... rich kids from $\{$ suburb $\}$. And they're ${ }^{\wedge}$ slumming $^{\wedge}$

0420 Because they're. . whatever, you know. . Like whatever cliché in their life. .

0424 And they feel like. . oh you know. .

0426 My parents don't understand me

0427 Society doesn't understand me\} \{mocking, whiny sounding\}

0428 But it's also. . uh . . . Man it's a subculture. It's great. . like. .

$0433 \wedge^{\wedge}$ Drugs $^{\wedge}$ and ${ }^{\wedge} \operatorname{Dogs}^{\wedge}$ and $\wedge^{\wedge}$ traveling $^{\wedge}$ and $\wedge^{\wedge}$ trains $^{\wedge}$ but . . I d don’t know 0439 \{It's empty\} \{facetious\}

P immediately picks up the thread with his own story:

0440 P: Peeing yourself . . . [laughter] after drinking too much [yeah]

0442 I got on the MAX and there was like this troupe full of homeless people

0445 that got on with their dogs and bags and everything.

0447 And they reeked of fucking ${ }^{\wedge}$ urine $^{\wedge}$ and ${ }^{\wedge}$ booze $^{\wedge}$

0450 And they're all like

$0451\{$ "Yea $=$ ah we got $\mathrm{so}=\mathrm{o}$ trashed last night.

0453 You passed out and then pissed yourself maan

0455 It was awe=some" $\} \quad$ \{imitates drunk sounding homeless person\}

0456 I'm like. . [chuckles]

0457 Is that what you really want to do

0500 when you're homeless\} \{raised, mocking voice\} [Laughter]

This is followed up by several sympathetic comments about "older people," people who actually are desperate. "Usually they're homeless. . for a reason and they're not just. . some rich kid from \{suburb\}. And they actually have [well] a. . problem or. . whether it be a drinking problem or a mental health [yeah]" (J, 0559-0608). Subsequently, most of the comments and stories about the first group, the "genuinely" homeless, are relatively sympathetic; the 
sharpest humor was directed toward the second group, the suburban kids out "slumming." Given the boheme sympathies of several members of the group, this sharp criticism of "kids from the suburbs," perhaps acting according to an idealistic vision similar to their own, is particularly interesting. The implicit contrast between the genuine and the pretense becomes explicit in an extended discussion of Jack Kerouac and Charles Bukowsky later in the conversation, to which I will return.

Later, after P mentions that Portland is a magnet for runaways, J concurs: "My best friend from Kansas was totally gonna move here when I lived here. Just. . [just as], I mean. . because [yeah] and I was like. . You fucking idiot [Laughs] it's just stupid" (J, 1524-1531). R embellishes the point: "Yeah, you don't know about rain do you?" (R, 1532). [Laughter]

In a story directed at the situation of homelessness at least as much as at homeless people themselves, J describes a video-game idea, which P links to an episode on a popular TV program:

$4845 \mathrm{~J}$ : I once had a concept for a video game. . there're bummer zombies

4848 and you had to like shoot the zombies. . but not the bums

4851 and they would all come after you. . like awwww ...

4855 S: that's a great idea (laughter)

4857 P: ^ Change! Change!^

4859 have you seen that South Park episode? . .

4902 it was on the last South Park. . it was like the night of the living bums

$4907 \wedge^{\wedge}$ and $^{\wedge}$ basically bums invaded South Park

4909 and they're all just going around

$4911{ }^{\wedge}$ Change! Change!^

4913 (general laughter)

4916 R: That's how it is in Portland! . .

4918 the key is if you see somebody approach

4920 you hit them up for money first (haha)

This extended passage is interesting in several ways. P might have spoiled J's performance (by alleging that the idea originated with the TV show) but instead reinforced it by repeating basically the same idea while drawing the media connection. This and other instances of collaborative humor contradicts claims that humor is always in some sense competitive (e.g., Gruner 1997). It is a layered comparison (Clark 1996; see also Attardo's 2001 discussion of “intertextual" jokes) - J's (and P's) story contains the South Park episode, which in turn contains old horror movies, complete with a playful distortion of the title of a classic movie about zombies (Night of the Living Dead), 
rendering the troublesome encounters with people asking for money in a harmlessly comic image. As an apparent aggression against homeless people, this is rather mild, inasmuch as the implied criticism is softened and rendered comical by the implication that they are, like zombies, bereft of will.

\subsection{Scatological humor: Turning the tables}

Swearwords are frequent, and scatological humor appears throughout the conversation. The most interesting comes about thirty minutes into the conversation, when $\mathrm{J}$ repeats a possibly apocryphal story:

3937 J: On the east coast I think, Boston or somewhere

3939 my friend was telling me about this. . it was all over the news. . like. .

3941 homeless people were taking shits in peoples cars

3942 inside their cars. . because they didn't. .

3943 have a place to go the bathroom. . they, they would like get arrested

3945 or. . whatever because they yah know

3947 P: That's the number one public nuisance in Amsterdam

3948 J: So they started shittin in people's cars. . like inside their cars

3950 they'd get in, take a shit, get out and you come back to your car

3953 (general laughter)

3954 and there's shit

3955 R: that's ^ brilliant!^ That's subversive ... people who own cars wait!

3958 (general laughter)

4000 P: get a bike!

4001 R: shit! I drove (laughter)

4003 B: you can't shit inside somebody's bike.

This story appears to have been introduced in part as an illustration of the problems homeless people cause others, but it also has the characteristics of "a good story" of the picaresque genre, where the loveable scalawag gets the better of those who represent propriety and order. It is clearly enjoyed by everyone present both for the incongruous image (Attardo 2001; Gibbs 2006) and for the way in which the tables are turned on the middle-class automobile owners and on those who persist in commuting by car ("get a bike!") It is also interesting, given the frequency with which "shit" and other expletives appear in the transcript, that J used the euphemistic "to go the bathroom" while telling this story. This sense of ambivalence is reinforced by the transition from a literal 
use of "shit" (line 3954) to an exclamatory use (4001) and back to a literal use (4003).

In addition to this bawdy story about soiling people's automobiles, there were several more gently humorous stories in which the basic humanity of homeless people is celebrated. In one, J (who lives in an area of downtown Portland that has many homeless people) is asked how it is to live there, and prefaces his reply with the following story:

1859 J: No, like, when I first moved down there I was a little weird about it.

1902 Just, cuz'. . You know. . I always lived in the suburbs,

1904 And. . you know ... we had a couple of bums that lived. .

1907 behind our house. . in \{suburb\} [laughs] \{slower\}

1910 But. . they were friendly. They rode the-

1913 There was this huge hill, and they just, like, rode the shopping cart,

1914 all the way down the hill.

1915 S: Nice

1916 [Laughter]

1917 J: But, uh. . And they're like a married couple too

1922 I liked that, \{it was funny\} \{trails off\}

Somewhat later, S tells with obvious relish a story about a "bum" who turned the tables and got the better of her:

4436 S: I have had the funniest. . funniest bums though. .

4440 one of them asked me for a cigarette. . one and a half or two years ago

4443 I was like. . I don't have any.

4445 He pulled out a rosary!,

4447 He was like. . ^you're lying to the LORD!^

4448 (general laughter)

4452 and I was totally. . and I was like shit he called me on it

$4455 \wedge^{\wedge}$ he held up the rosary^

$4456 \wedge$ you're lying to the LORD!^

4457 he did a jig and ran down the street

4458 (general laughter)

\subsection{Making fun of "the system"}

In one of the first intrusions of material from the media, $\mathrm{P}$ describes a comedian's routine he saw on the web: "He was basically talking about being homeless. It was kind of a joke thing. But it was really real at the same time. He was 
talking about how everyone goes 'Well why don't you just go out and get a job?' And he's like 'Well, I can't go get a job because I don't have an address. And without and address, I can't. . get a paycheck' . . [yeah]' (P, 0730-0744).

This repeated comedy routine leads to a serious comment about cell phones as a substitute for an actual residence, which then leads into another long story about a homeless person "scamming the system."

0817 B: I guess the one thing that bothers me

0819 even when I was at the soup kitchen. I saw homeless people with. . . .

$0823 \wedge^{\wedge}$ I pods` [uh huh]

0823 And. .^cell phones^. And I'm like. . how are you affording this? When. .

0828 J: I once saw a lady at. . at the, the Pete- What is it? Peterson's?

0833 S: Yeah Peterson's, \{Pete-, Pete-\} \{fades out\}

0834 R: PA's?

0835 J: they have those cell phone tents. . out there, every

0839 on like, Saturdays. And this lady. . like. . sold this ^ bum $^{\wedge}$. . [uh huh]

$0842 \mathrm{~A}^{\wedge}$ cell phone ${ }^{\wedge}$ [oh yeah]. Like, right in front of me. And I was like,

0843 “Are you fucking kidding me?” like. .

0844 There's no way he's gonna be able to like

0846 S: Well the thing

0847 J: Ever pay his bill. . or it. .

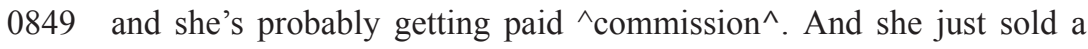
phone

0852 And he, he like called his mom right there

0854 he's like \{"I just got a phone"\} \{raises pitch, imitating voice\}

0855 He was so happy

[Laughter]

0856 I mean

[Laughter]

0857 R: Well that's great, like

0858 S: Yeah awesome

0859 J: You know but like. . wha-buh-duh, where's he gonna charge it? ...

0900 R: Uh...

[Laughter]

0901 P: Restaurants

0902 J: [Laughing] When is he gonna fucking pay

0903 Pay for his cell phone bill

0904 R: Well I mean everybody has

0906 J: He's just trapped in fucking a 2 year contract 
0908 That he's never gonna be able to pay [Laughter]

0909 R: Dude everybody has needs.

0910 P: Where are they gonna send the bill?

0911 S: That's good. Yeah, Yeah he worked the system

0913 P: Where they gonna send the bill?

0914 S: he gets a cell phone for a month [laughter] [unintelligible]

0916 S: They. . send a bill [yeah, that's good]

0917 whenever he gets another [unintelligible] [Laughter]

0918 J: he’s probably just gonna sell it. . I suppose.

Here, J seems to be simultaneously critical of the cell phone sales agent, as a representative of the stupidities of the capitalist system, and both critical of and sympathetic toward the homeless person. The ensuing interchange about charging it, paying the bill, etc., collaboratively reinforces the incongruity, but $\mathrm{R}$ restores the underlying issue of deprivation when he observes seriously that "Dude everybody has needs." (It is interesting that this comment did not come up during the many discussions of urinating and defecating on the street and in parks.)

In a serious vein, $\mathrm{S}$ observes "We all have jobs" and R interjects, "shitty." (2156). This theme is elaborated later, during a long discussion critiquing the Capitalist "system," when R says, "Like you know, its not the fittest will survive. Its like, the person who's willing to get fucked the most, and go through the most schooling, is gonna survive. Like. ." (R, 2427-2432). J (2434) interjects "Fuck the most. . other people over." [yeah] and R finishes, "Who [laughter] has no conscience" [yeah, exactly]." There are many examples throughout the conversation in which a serious observation is undermined or at least qualified by ironic or joking back-channel comments.

\subsection{Making fun of higher education}

During a long section in which the participants criticize the capitalist "system," higher education (the local university in particular) becomes the butt of the critique - and of the humor: "There is no one way to live life. And I think the, the homeless. . the word homeless, itself is, uh. . is like a fuckin buzz word or whatever. [yeah] Its one of those, topics, that you pick out of a. . \{university 
initials, spoken emphatically\}, you know, research paper. [laughter] And uh. . that's, I don't know [laughter] that's bullshit, its just like a bunch of, white kids. . sitting in \{a suburb . . discussing it. ( $R, 2557-2619$ ).

A few minutes later, $R$ extends the critical humor to embrace the participants in the conversation themselves: "Th, the people that are going to school in this room we're going. . yes, quote, 'to help people' as we all like to say, but. . naw, communication majors, they're goin to make ^${ }^{\wedge}$ money $^{\wedge}$." (R, 2923-2932). S reinforces the point about materialism: "Yeah, absolutely." Then J picks up the critique with a JOURNEY metaphor: "It's education, its everything else too, the whole fucking country [yeah] is fucked. And if you don't go with this thing that's bigger that you [yup] and its going this direction, if you can't jump on that ship, you're fucked. [stifled laughter] That's the way life is. I mean [laughter] seriously, [laughter] that's what it is" (J, 2901-2915). It appears that J intended these comments seriously, but others picked up on the humorous elements as well as the underlying serious intent of the metaphor. This kind of "conversation management" humor occurs frequently during the last half of the conversation.

\subsection{Conversation management humor}

In several places, one or another of the participants "gets too serious," and humor is used (sometimes by others, sometimes by the speaker himself) to moderate the serious tone. $\mathrm{R}$, who has himself experienced several periods of homelessness and displays an apparent radical left political consciousness in several parts of the conversation, was a frequent target. For example, at one point R suggests that there is "An illness within society, like, um. . completely interrelated with drugs ... and mental illness uh ... infantile sexuality no, whatever [ha ha] like ... [Laughter] some- [laughter] Seriously, like, something" [laughter] $(\mathrm{R}, 1105-1117)$. R's tone here is self-effacing and appears to combine a high-minded use of complex concepts with a low-key self-mockery. Later, when $\mathrm{R}$ is talking seriously about the prospect for homelessness to get worse, and predicts a general societal collapse, one of the other participants exclaims, "Homeless of the world, unite!" In these passages and several others, $\mathrm{R}$ combines seriousness with self mockery: When the group turns his comments into a joke, he goes along with the humor, then attempts to steer the conversation back to a more serious tone.

In another example, after another long monologue in which he predicts a general collapse of civilization, $\mathrm{R}$ brings up Africa as an example. 
4142 R: Look at Africa. They call it genocide, they call it famine

4145 and you read it so conveniently on your iPhone and everything

4148 S: I don't.

4150 R: and it scrolls. . its $\mathrm{s}=\mathrm{o}$ user friendly. .

4153 J: We don't look up shit about Africa

4154 (general laughter)

4156 R: even better. That surmises everything. Africa ... (cough)

4200 uh. . no. . that's, that's it! That's exactly where we are headed.

4203 S: Africa?

4204 (general laughter)

4207 jumping on a ship. Lets go!

4210 R: to Africa

4211 (general laughter)

This exchange is interesting on several levels. It is very likely that $\mathrm{S}$ understood R's comment about "that's where we are headed" as metaphorical, but by treating it as a literal declaration of travel plans, S deflated the hyperbolic vision of apocalyptic doom $\mathrm{R}$ had just sketched, and thereby re-instated the mood of merriment.

In what starts out as more social critique, $\mathrm{R}$ begins

3652 R: I think of housewives and pills and unhappiness uh ...

3653 [sounds like happiness] spouses cheating. .

3654 shitty parents! ${ }^{\wedge}$ Think about ${ }^{\wedge}$ all the times you heard your parents fight

3656 you know. . ^fuck marriage!^

3658 its another institution that perpetuates homelessness!

3659 S: ${ }^{\wedge}$ there you go ${ }^{\wedge}$ (general laughter)

$3700 \wedge$ ^you write that shit down I want that transcribed!^^

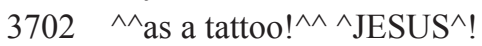

At that point, $\mathrm{R}$ begins teasing $\mathrm{S}$, and others join in:

3704 R: But seriously, that's a nice iPhone you got there (laughter)

3706 S: I love my iPhone ... I ain't homeless. .

3708 B: How do you believe your iPhone connects you, uh. .

$3710 \quad \mathrm{~S}:{ }^{\wedge}$ the homeless ${ }^{\wedge}$ ?!

3711 B: to the homeless

3712 (general laughter)

3714 S: I can google them. . I can google the homeless of Portland!

3716 BB: ${ }^{\wedge} \mathrm{Or}^{\wedge}$, she can call the guy,

3717 who got the two month free contract. [no I could!] 
3718 S: I could call that homeless person or um ...

3723 I put it in my purse when I see them

3724 and then I put my purse in my jacket (haha)

Here, the group picks up on two themes from previous humorous anecdotes and makes fun of their own culture and its obsession with cell-phones and other instant communication media. At the end, S connects the joking about cell-phones with the idea that people might be afraid of homeless people in a playful, joking way.

A few minutes after this exchange, $\mathrm{P}$ tells a story about how he responds to requests for a change or a cigarette he insists on something in return:

5039 P: Ok! . . it I ever have a guy ask me for something like that,

5042 I always ask them what they're gonna give me for it . .

5046 R: yeah!

5048 P: Because I wanna anecdote. . I want some like story. .

5051 or something like that. I find it to be a fair trade to get something out of it.

5056 R: Yes! Deconstruct yourself to their level. . that's the hierarchy ...

5104 what we tell ourselves is that we're better than these people ...

5108 these people are subhuman. Its not that at all. They're you and me,

5112 your second cousins whatever sister. That's who they are

5116 they're people and they have families and situations. .

5119 reasons for the way they are (long pause)

5124 yah like sit there.

5125 Ok! Yeah sit there ok? Here's a cigarette you can have

5129 one of mine a cigarette. Tell me a story

5133 I am gonna smoke a cigarette with you. Like ${ }^{\wedge}$ whats up man?^

5137 Where are you from? Like they're human you have to

5141 like. . treat them like this dirty nastiness

5143 P: If I . .if I ever do give something out that's my requirement

5147 [ that you get something]. . get something

The next line is unintelligible, but it appears that $\mathrm{S}$ asked $\mathrm{P}$ what he had given in exchange for a cigarette he had asked for.

5152 P: my company

$5154 \mathrm{~S}:{ }^{\wedge}$ Fuck!^^ I want the cigarette back!

5157 I gave you fifteen hundred cigarettes over the last six years.

5200 What do I get for it? 
5202 P: vv my company vv

5203 (general laughter)

5205 \{unintelligible\}

5207 good memories! Good memories! . . .

Participants also frequently turned the "conversation management" humor against themselves, deliberately undermining their own seriousness. $\mathrm{R}$ in particular uses this technique throughout the conversation. For example, after a long bit about people feeling alienated with their family, R remarks, "Shit. . that's why I've been homeless, you know, like. . [Laughter] ^Fuck^ payin' rent! I can save money, and sleep on the streets, but. . . I don't know ... What do you think?" [laughter] (R, 1419-1429). Near the end of a long social critique, $\mathrm{S}$ talks about how to get people to stop using drugs, and $\mathrm{R}$ exclaims, "Hey, we are these people, S-----" (R, 2526) There ensues a discussion of quitting drugs, at the end of which S says, "I stopped because the girl I bought drugs from ran out." (S, 2545).

\subsection{General playfulness; making fun of ourselves}

There is a good deal of teasing and joking about material possessions, including the previously described bit about cell-phones, and a bit directed toward one of the moderators about his salmon-colored sweater. P reminds one of his friends about an earlier episode in which they thought about running away to Washington or California, and the group exchange fantasy quips about being homeless in California, where "everyone has a Coach purse and an iPhone, and even the homeless get plastic surgery." In a different passage, after a critique of "shitty parents," there is a series of ironic exchanges about the prediction that members of this group will be better parents.

Comparing humans to other animals, R comments, "Well ^hey!^ look at uh. . look at every other animal. . though enn every other animal. . by our definition would be homeless, and all ${ }^{\wedge}$ we are is animated dirt, and uh. . guts, and uh. . shit, and cum and uh ... piss and bile ${ }^{\wedge}$ (general laughter) (coughing) ${ }^{\wedge}$ just like every other species ${ }^{\wedge \wedge}$ on. . the vplanetv. . though so like how come we don't like. . you know. . consider other animals on the planet homeless like. . well the society its so confusing. . ^Yah!^ but. . (R, 3039-3107). S (3123) asserts that "then it comes back to possession," and R responds, "Which ${ }^{\wedge} \mathrm{I}^{\wedge}$ think is. . is the knack of society like. . like uh. . hey it's a great white like. . uh ${ }^{\wedge} \mathrm{I}$ own you bitch^ [well. . uh] like ${ }^{\wedge}$ we're going to have $s=e^{\wedge}{ }^{\wedge}(R, 3125-3132)$. 
In a later section of the sustained social critique, $\mathrm{R}$ says, " $\wedge \wedge$ and its $\mathrm{s}=\mathrm{O}$ funny like uh. . just going through the motions like. . its like. . seen it sold" (laughter). (R, 3312-3316). It's not clear what R was referring to, but J asks, "Seamen? Sold?" and P follows up, "did you say semen?" "Yah" (R, 3321). "Not semen" (S, 3323). (general laughter) "^Come on!^" (R, 3324). This culminates in another bit of teasing about the research purposes of the conversation: "Edit that out" (P, 3326).

Two instances of self-parody occur during a discussion of the "noble outcast" ideal, during which Jack Kerouac and Charles Bukowski are discussed at length. S says "^Its romantic!^," but not "in the like. . Julia Roberts movie kinda way" (S, 3405-3409). Then P begins a fantasy, "I would love to be that guy who travels [its this big beautiful idea] [yah] just able to . . not having to worry about. . in one place [so then nomadic life?]" (P, 3413-3417). R picks up on the theme and begins a riff, "Yah its like where you didn't have to worry about" ( R, 3421), P chimes in with "like your cell phone and your computer and. .” (P, 3422), and R finishes the riff, “^yeah!^ and like my new clothes and. . and my mortgage bill and my cell phone. [yeah] I feel so insecure." (3424-3437). At the end of the noble outcaste narrative, $\mathrm{R}$ repeats the trite phrase, "what we consume is how we are. Like what have we consumed today?" (R, 3439-3440). S replies, "I drank cigarettes. (general laughter) [literally] No seriously! I drank cigarettes and a seven layer burrito.” (S, 34433446).

Following a discussion of overpopulation S spins his own fantasy of how to solve the homeless problem: "then we'll eventually run out of oil and then bury them and turn them into oil. That's my plan." (general laughter) (S, 35013505).

\subsection{Meta-communication: Humor about the research itself}

There were several cynical remarks about the research project for which the conversation was conducted. When one of the moderators asks J, who has been relatively quiet for a while, if "there is anything else. . like that has floated though you head or like. ." J responds, in a quiet voice, "No not too much. Just trying not to think about it too= much" (general laughter) (B, J, 4222-4227).

At the very end, S asks the moderator, "Satisfied yet?" J suggests "just say a bunch of foul shit into the (chuckle). ." and one of the moderators adds, "Seven dirty words of George Carlin [yah uh. . ] umm. . I think you've said most of them [haha]." The other members of the group then do an inventory of the 
“dirty words" everyone spoke, ostensibly to be sure Carlin's (1972) entire list had been covered.

\subsection{Summary}

As one would expect, some of the humor is at the expense of the lower status homeless people, particularly at the expense of kids "from the suburbs" who go "slumming," and some is at the expense of "the system," including the educational system, which has power over the participants. But much of this seems more like playing with the language than any expression of spite or maliceand there is also an abundance of humor that expresses sympathy, if only indirectly, for the plight of the homeless. There are repeated instances of affectionate teasing within the group, including teasing that seems to be directed at keeping the discussion from "becoming too serious," and maintaining a tone of enjoyable sociability. A disproportionate part of this teasing is directed at R, who as a result of his own experiences of homelessness and his leftist political leanings seems more disposed than the others to serious political monologues. However, $\mathrm{R}$ takes it in good part and in several instances joins in, making fun of himself and using self-directed humor as a way of managing the conversation. Indeed, much of the teasing directed at $\mathrm{R}$ seems to express an underlying respect for the fact that he has led the most Boheme life-style, that he has actually experienced what he talks about. $\mathrm{R}$, in turn, repeatedly teases $\mathrm{S}$ for her apparent materialism. Both $\mathrm{R}$ and $\mathrm{S}$ take the teasing in good part and in several instances join in, making fun of themselves. There is no evidence that any participant is in any sense excluded from the easy camaraderie of the group at any point, or that any participant takes offense at the teasing. Humor is found throughout the conversation, but it becomes both more frequent and more playful toward the end than in the beginning, perhaps reflecting the group's growing comfort (or boredom) with the topic.

\section{Discussion}

Humor appeared throughout this conversation, which is not surprising in a group composed of single men and women in their mid-twenties. Interestingly, there were no conventional jokes, aside from a few references to comedy routines from mass media, and only a handful of puns. There were many stories, some quite short and others extended, some serious, some told with humorous 
intent, and others told with serious intent but converted into humor by the responses of listeners. There were also many examples of mock-insulting "putdown" humor similar to that described by Terrion and Ashforth (2002), along with word-play and copious use of expletives.

\subsection{Implications for humor theory}

Consistent with previous research (Gruner 1997; Zillman and Canto, 1976), mock-aggressive humor appears throughout, as does humor based on incongruous images (Attardo 1994; 2001; Perlmutter 2002; Raskin 1985; Raskin and Attardo 1994); often these two themes appear in the same segment. However, the nature and target of the disparagement shifts as the conversation progresses, from stock images of homeless people begging beside the freeway with "a sign and a dog," to disparagement of "rich kids from the suburbs" who are characterized as "slumming," to a more general disparagement of conventional society, which is observed much more frequently than disparagement of "genuine homeless" people, especially in the last half of the conversation.

Much of the apparently aggressive humor takes the form of teasing. Consistent with Norrick's (1993) observation with respect to the family and friendship groups he studied, these overtly aggressive jokes and quips are apparently enjoyed as much by the "victims" as by the others, and seems to serve a social bonding function (see also Attardo 2001; Gibbs and Izett 2005). The tone throughout is playful and light-hearted; only in a few cases does it have even a hint of the bitterness or anger one would associate with genuine aggression. Even the humor directed at "the system" generally, or at the university in which some of the participants are enrolled, fails to show signs of genuinely aggressive intent. These instances include sarcastic comments about research papers (sometimes explicitly including the research assignment for which this conversation was itself being taped) or ironic contrasts between the comfortable lives of those participating in the research and the hardships experienced by the homeless people who were the topic of the conversation.

Most of the humor is more playful than aggressive in tone, consistent with Martin (2007). Even in the many instances in which humor is used (by himself and others) to mitigate R's politicized monologues, or by R (and others) to criticize the consumerist leanings of group members ( $\mathrm{S}$ in particular), there is no evidence they are intended or taken as attacks on the target's integrity, standing in the group, or even the ideas they express. Some of the data could be interpreted in support of a disparagement or aggression theory of humor, but 
only at the expense of obscuring the important distinction between the genuinely hostile aggression of sexist or racist jokes or put-downs directed at a rival or a disliked outsider, and the mock-aggression of playful insults exchanged between friends.

As Gibbs (2006) observes with respect to metaphor, humor is a complex phenomenon and it is unlikely that a single theory will account for all aspects of it. Superiority and aggression must certainly play an important part in some humor, but the attempt to apply superiority and aggression to all humor requires so generalizing these concepts that they are rendered almost meaningless. Similarly, humor often seems to involve the abrupt resolution of an incongruity, often in a way that results in an abrupt increase in relevance (Ritchie 2005; Yus 2003), but many of the instances of apparent humor identified in the foregoing do not involve any incongruity beyond play with words and sounds. As one of the anonymous reviewers pointed out, word-play itself, especially when it involves distortion of sounds or ordinary meanings, can be considered "incongruous," but that form of incongruity is quite different from the incongruous images associated with, for example, homeless people soiling peoples' automobiles or riding down a hill in a shopping cart, or the exaggerated incongruities found in conventional jokes about impossible or improbable events such as an animal ordering a drink in a bar or an elephant hiding in a strawberry patch (see also Martin 2007).

\subsection{Humor in managing conversation}

Humor is used throughout the conversation to help maintain a balance between the playful, joking tone of a social interaction among friends and the more serious tone of a topical discussion called for by the framing task of collecting research data; this use of humor included several instances of teasing and joking about the research task itself. Humor is also used in several places (often by $\mathrm{R}$ himself) to shorten or moderate R's long monologues in the interest of maintaining an equitable distribution of speaking turns and a convivial tone.

\subsection{Negotiating social relationships and identities}

Several studies have shown how humor is used to establish and maintain relationships, and establish individual identities within these relationships in work groups (Holmes and Marra 2002; Plester and Sayers 2007; Terrion and 
Ashford 2002) and within families (Everts 2003; Norrick 1993). Teasing and "put-downs" can be important in maintaining relationships both within work groups (Plester and Sayers 2007; Terrion and Ashford 2002) and among family members and friends (Everts 2003; Norrick 1993), and this form of humor is seen throughout the homelessness discussion. In this conversation, as in the conversations reported by Everts, silliness, fantasy, and language play are also used extensively, both for relational purposes and for negotiating participants' individual conflicting identities.

The social identity process in this group appears to be quite complex. In the culture of the Western United States, young adults often enjoy a few years after completion of high school in which they are relatively free of responsibilities; they may travel, change jobs, apartments, and romantic partners frequently, drop in and out of college. Several of the participants in this conversation had previously experimented with the exaggerated freedom of the "hippie" lifestyle, including the use of inexpensive alcohol and illegal drugs typically associated with "street people." Possible concerns about substance abuse and "quitting" are themselves joked about in S's comment (line 2545) that "I stopped because the girl I bought drugs from ran out."

All of the participants are at a life stage when young people typically begin to think about career, marriage, and a generally more stable, less "free" lifestyle. As the prolonged exchange about Bukowsky and Kerouac demonstrate, to varying degrees they identify both with the conventional middle-class groups who disapprove of homelessness and with the "real" homeless people, while disparaging the "slumming" of "rich kids from the suburbs" who play at being homeless. Much of the bawdy humor, as well as the extensive use of expletives throughout the conversation seems to express these conflicting social identities.

An important aspect of both cultural and individual identity is memory. Schank and Abelson (1995) argued that memory is at the individual level primarily based on stories. Although Schank and Abelson do not discuss the role of story-telling in collective memory, it is evident, especially in the data reported by Everts (2003), that retelling familiar stories, often but not always humorous stories, is important both to group cohesion and to establishing and maintaining individual identities within a group. In the conversation analyzed in this essay, humorous stories are used in several places to establish individual identities with respect to both this group and other groups and, as noted in the preceding paragraph, to work out the participants' ambivalent attitudes toward the "real" homeless people, the rich kids slumming," and the manifestations of "the system," including the university in which some of them were enrolled at the time of the conversation. Thus, the conversation shifted frequently be- 
tween humorous anecdotes that disparaged homeless people, excused or even celebrated homeless people, disparaged conventional middle class mores and values, reinstated or justified middle class mores and values, and so on. It is also notable that the themes from one story are frequently repeated and developed in later stories, a process similar to the repetition and development of metaphors which Cameron (2007) identifies as a vehicle for relational development.

\subsection{Constructing an understanding of homelessness}

The task set for the group was to "discuss," and by implication to increase their understanding of homelessness as a state of existence. The conversation started with stock images and narratives of homeless people begging for change (certainly the most visible aspect of homelessness), and proceeded with many other narratives, many of them told in a way to bring out their humor, that illustrated different aspects of the homelessness problem.

The repeated joking references to defecation and urination seemed to serve an important function by introducing in a humorous way the practical difficulties (and associated humiliations) experienced by homeless people in an urban environment in which available toilets are frequently locked or reserved "for customers only." The banter about the homeless person acquiring a cell-phone and R's self-mocking reference to his own homeless experience as a "have-atent kind of homelessness" extend this to a more general awareness of the disconnect between the taken-for-granted accessories of modern life and the very real deprivations of homelessness.

\subsection{Topics for future research}

The foregoing analysis suggests several avenues that may prove fruitful in future research. Dunbar's $(1996 ; 2003)$ ideas about the "grooming" function of language use calls out for further research on how the shared pleasure of humor and other forms of language play contribute to social bonding, independent of the actual content (see also Attardo 2001). The playful and metaphorical elements in humor have only recently begun to receive the attention they merit (Martin 2007): It would be useful to explore the use of word-play and language play generally in humor. Similarly, Schank and Abelson's ideas about the role of stories in individual memory suggest a fruitful line of inquiry into the way 
humorous stories build and maintain group identities (and common ground), and the use of these stories as a resource for building social relationships through shared enjoyment.

This research was conducted within a purely social group, convened to discuss this topic at least in part as a favor to the two moderators, to assist the moderators in a school project, and its generalizability is accordingly limited. Future research will extend this approach to other informal conversations as well as to observation of interactions among task-oriented groups as they discuss a variety of complex issues that evoke ambivalent responses.

\section{Conclusion}

The participants in this conversation represent a diverse range of social backgrounds and political views, ranging from new-left radicalism to moderate political and social conservatism. This range of life experience and political and social views is apparent throughout the conversation: These friends have discussed social and political issues before, and they are well aware from the beginning of the conversation of the differences among their views. The humorous stories as well as the joking and teasing provide a low-threat means to express their nuanced views, and allow individual members of the group a means to express both disapproval of and sympathy for homeless people. The group does not arrive at anything like a consensus during this conversation, but through the stories and teasing members of the group are able to work out their individual identities with respect to the topic and the group, expressing a more nuanced view of homelessness without by any means conforming to a unitary group norm. The social solidarity of the group does not seem to be threatened by this internal diversity; rather, the diversity is rendered as a source of mutual enjoyment through the teasing and joking.

Many of these stories have clearly been told before, in other social settings, and those that elicit a favorable response (the "good stories") will be repeated, with narrative improvements, in future social interactions. Thus, this conversation reveals an ongoing process through which the culture comes to terms with the troubling issues surrounding homelessness, a process in which humor plays a crucial role. The media-based humor (the web comedian's routine, the reference to Carlin's "seven words" monologue, and the episode from South Park) plays an obvious role in this process; stories like homeless people relieving themselves in people's cars and the homeless person getting a cell phone are equally important. Humor, like metaphor, plays an important cognitive as well 
as emotional role in facilitating the expression and dissemination of facts ("Dude, homeless people have needs too") and their implications (if public toilets are unavailable or locked, people will relieve themselves wherever they can).

These data also illustrate a playful dimension of humor that is too often neglected. It is apparent throughout that the participants thoroughly enjoyed the conversation and the humor, including the teasing and mock-insults. Dunbar (1996) has proposed that language originally developed as an extension of primate "grooming," a way both to create and maintain coalitions by giving each other pleasure and to learn about social structure through "gossip." Both types of functions, learning about the social structure ("gossip") and bonding through shared pleasure ("grooming") are apparent in the joking among this group of friends. Even the apparently aggressive teasing is evidently enjoyed by all parties in this conversation (Martin 2007; Norrick 1993; but see also Drew 1987). There is evidence in these data that group solidarity is maintained through humor that differentiates the group both from the homeless on one hand and from conventional society on the other, as well as through humorous teasing based on intra-group differences. Most of all, the shared enjoyment of the stories, the jokes, and the teasing contributes directly to maintaining the solidarity of the group.

The conversation reported herein provides an example of how humor is used not only to reduce intra-group tensions resulting from differences in social and political views, but also to introduce unpleasant and potentially objectionable information into the mutual awareness or of group members, thus building "common ground" (Clark 1996) and to facilitate the participants' development of more nuanced and complex responses to the topic of homelessness, within the context of membership in and identification with the group. The result is not a consensus or even any decrease in differences among group members' opinions, but the participants did seem to accommodate their views to the group by expressing a more complex understanding of the issue itself as well as of the range of responses people have to the issue. The combination of incongruous images and sentimental humor introduced during the conversation renders it easier for participants to acknowledge the humanity (and complex motivations) of homeless people without necessarily accepting or approving of their lifestyle or specific behaviors.

Humor, abetted by narratives and metaphor, served the group well in several ways. Humor helped to maintain an appropriate tone throughout the conversation, facilitated introduction of otherwise embarrassing or awkward topics, and provided a vehicle through which participants were able to work out the 
conflicts and contradictions within their own shifting social identities in relation to the complex topic of homelessness. The incongruities brought out by many of the humorous stories reflect the incongruity of the phenomenon of homelessness in the midst of plenty, and also reflect the incongruities experienced by young people at a stage in life when they are giving up the freedom and irresponsibility of youth in exchange for the more mature satisfactions of career and family. Although much of the humor used in this discussion appeared at first glance to express speakers' felt superiority (with respect to homeless people, "rich kids from the suburbs," and middle class mores and values of "the system"), the raw edge of its apparent aggressiveness was tempered throughout by a more gentle and playful form of humor that celebrated the essential dignity and humanity of the homeless people.

It seems likely that these and similar jokes, quips, and teases are repeated in multitudes of conversations, by these people in other social settings and by other young people like them. This interlocking network of conversations provides a primary medium for the dissemination of information and the formation and transformation of views about societal issues (see Cameron 2007). The humor plays a complex role including motivating the spread of information and attitudes as well as facilitating the expression of troubling and often mutually contradictory responses. By analyzing the use of humor in casual conversations of this type we can gain a clearer understanding of the smallscale interactions through which "social reality," including public opinion, is formed, transmitted, and transformed.

Portland State University

\section{Notes}

Correspondence address: cgrd@pdx.edu

Author's Note: The conversation reported herein was moderated, transcribed, and coded by two students, Berlin Boyer and Brandon Ellison, as part of a class project. Their assistance is deeply appreciated. The final version of the manuscript benefitted from the helpful comments and suggestions of Brandon Ellison and three anonymous reviewers.

\section{Appendix A: Transcription symbols:}

Lines are numbered in four digits, with the first two digits representing the number of minutes into the conversation and the second two digits representing seconds. 
Speech overlap

[within square brackets]

Transitional continuity

Completion of a thought

Continuing

question, uncertainty, or appeal

Pauses

short pause

long pause

Emphasis

Terminal accent

segment of louder speech

Vocal noises

Laughter

[laughter]

In-stream disfluencies and sounds

\{transcribe phonetically, example: eh heh, umm \}

Analyst's comments and omissions analyst's comments

\{enclosed within swirly brackets\}

Quip will be used throughout to distinguish the kind of short, witty remark exemplified by epigrams and word-play from puns and the narrative form of jokes, both of which have been far more extensively studied in previous research.

Portland's light rail system.

Portland is a famously bicycle-oriented city, especially among liberal young adults.

\section{References}

Apter, Michael J. 1982. The experience of motivation: The theory of psychological reversals. London, UK: Academic Press.

Attardo, Salvatore. 1994. Linguistic theories of humor. Berlin: Mouton De Gruyter.

Attardo, Salvatore. 2001. Humorous texts: A semantic and pragmatic analysis. New York: Mouton de Gruyter.

Camern, Lynne J. 2007. Patterns of metaphor use in reconciliation talk. Discourse and Society $18.197-222$.

Capozza, Dora, \& Rupert Brown (eds.). 2000. Social identity processes: Trends in theory and research. Thousand Oaks, CA: Sage.

Carlin, George. 1972. Seven words you can never say on television. From Class Clown. Los Angeles, CA: Atlantic.

Carter, Ronald. 2004. Language and creativity: The art of common talk. NYC, NY: Routledge.

Chiaro, Delia. 1992. The language of jokes: Analyzing verbal play. London, UK: Routledge.

Cook, Guy. 2000. Language play, language learning. Oxford, UK: Oxford University Press.

Crisp, Richard J. \& Miles Hewstone. 2000. Multiple categorization and social identity. In Capozza, Dora, and Brown, Rupert (eds.). Social identity processes: Trends in theory and research, 149-166. Thousand Oaks, CA: Sage.

Drew, Paul. 1987. Po-faced receipts of teases. Linguistics 25. 219-253. 
Dunbar, Robin I. M. 1996. Grooming, gossip, and the evolution of language. Cambridge, MA: Harvard University Press.

Dunbar, Robin I. M. 2003. The social brain: Mind, language, and society in evolutionary perspective. Annual review of Anthropology, 32, 163-81.

Ellison, Brandon \& Berlin Boyer. 2008. Metaphor use and the perceptions of homelessness. Paper presented at the annual conference of the Northwest Communication Association, Coeur d'Alene, Idaho.

Everts, Elisa. 2003. Identifying a particular family humor style: A sociolinguistic discourse analysis. Humor: International Journal of Humor Research 16. 369-412.

Fagen, Robert. 1995. Animal play, games of angels, biology, and Brian. In Anthony D. Pellegrini (ed.). The future of play theory: A multidisciplinary inquiry into the contributions of Brian Sutton-Smith, 23-44. Albany, NY, USA: State University of New York Press.

Fine, Gary A. \& Michaela DeSoucey. 2005. Joking cultures: Humor themes as social regulation in group life. Humor: International Journal of Humor Research 18. 1-21.

Gamson, William A. 1992. Talking politics. Cambridge, UK: Cambridge.

Gibbs, Raymond W., Jr. 2006. Metaphor interpretation as embodied simulation. Mind and Language 21. 434-458.

Gibbs, Raymond W., Jr. \& Christin D. Izett. 2005. Irony as persuasive communicationin Herbert L. Colston \& Albert N. Katz (eds.). Figurative language comprehension: Social and cultural influences, 131-152. Mahwah, NJ: Lawrence Erlbaum.

Glucksberg, Sam. 2001. Understanding figurative language. Oxford, UK: Oxford University Press.

Gruner, Charles W. 1997. The game of humor: A comprehensive theory of why we laugh. London, UK: Transaction.

Holmes, Janet \& Meredith Marra. 2002. Over the edge? Subversive humor between colleagues and friends. Humor: International Journal of Humor Research 15. 65-87.

Kohn, Alfie. 1986. No contest: The case against competition. Boston: Houghton-Mifflin.

Lefcourt, Herbert M. 2001. Humor: The psychology of living buoyantly. NYC, NY, USA: Kluwer Academic/Plenum.

Martin, Rod A. 2007. The psychology of humor: An integrative approach. Amsterdam, The Netherlands: Elsevier.

Norrick, Neal R. 1993. Conversational joking: Humor in everyday talk. Bloomington, IN: Indiana University Press.

Perlmutter, Daniel D. 2002. On incongruities and logical inconsistencies in humor: The delicate balance. Humor: International Journal of Humor Research 15, 155-168.

Plester, Barbara A. \& Sayers, Janet. 2007. "Taking the piss": Functions of banter in the IT industry. Humor: International Journal of Humor Research 20, 157-187.

Raskin, Victor. 1985. Semantic mechanisms of humor. Boston, MA: D. Reidel.

Raskin, Victor \& Salvatore Attardo. 1994. Non-literalness and non-bona-fide in language: An approach to formal and computational treatments of humor. Pragmatics \& Cognition 2(1). 3169.

Ritchie, L. David. 2005. Frame-shifting in humor, irony and metaphor. Metaphor and Symbol 20 , 275-294.

Ritchie, L. David \& Valrie Dyhouse. 2008. Hair of the frog and other empty metaphors: The play element in figurative language. Metaphor and Symbol 23, 1-23.

Sasson, Theodore. 1995. Crime talk: How citizens construct a social problem. NYC, NY: Aldine De Gruyter.

Schank, Roger C. \& Abelson, Robert P. 1995. Knowledge and memory: The real story. In Robert S. Wyer (ed.). Knowledge and memory: The real story. Advances in Social Cognition, Vol. VIII. 1-86. Hillsdale, NJ: Lawrence Erlbaum Associates. 
Suls, Jerry M. 1972. A two-stage model for the appreciation of jokes and cartoons: An informationprocessing analysis. In J. H. Goldstein \& P. E. McGee (eds.). The psychology of humor: Theoretical perspectives and empirical issues, 81-100. New York City, NY: Academic Press.

Tajfel, Henri \& John C. Turner. 1986. The social identity theory of intergroup behavior. In Stephen Worchel \& William G. Austin (eds.). The psychology of intergroup relations. Chicago, IL, USA: Nelson-Hall.

Tannen, Deborah. 1984. Conversational style: Analyzing talk among friends. Norwood, NJ, USA: Ablex.

Terrion, Jenepher Lennox \& Blake E. Ashforth. 2002. From 'I' to 'we': The role of putdown humor and identity in the development of a temporary group. Human Relations 55. 55-88.

Worchel, Stephen, Jonathan Iuzzini, Dawna Coutant \& Manuela Ivaldi. 2000. A multi-dimensional model of identity: Relating individual and group identities to intergroup behavior. In Dora Capozza \& Rupert Brown (eds.). Social identity processes: Trends in theory and research, 15-32. Thousand Oaks, CA: Sage.

Zillmann, Dolf \& Joanne R. Cantor. 1976. A disposition theory of humor and mirth. In Anthony Chapman \& Hugh Foot (eds.). Humor and laughter: Theory, research, and applications, 93115. London: Wiley. 
Copyright of Humor: International Journal of Humor Research is the property of De Gruyter and its content may not be copied or emailed to multiple sites or posted to a listserv without the copyright holder's express written permission. However, users may print, download, or email articles for individual use. 